\title{
Effects of Protein-Modifying Reagents on Brain Tryptamine Binding Sites: Possible Involvement of a Thiol Group in Temperature-Induced High-Affinity $\left[{ }^{3} \mathrm{H}\right]$ Tryptamine Binding Sites
}

\author{
Shigefumi SERIKYAKU, Michiko SAITO and Ryoichi ISHITANI* \\ Group of Neuropharmacology. Josai University. Sakado. Saitama 350-02. Japan
}

Accepted September 13, 1989

\begin{abstract}
To investigate the biochemical nature of temperature-induced highaffinity $\left[{ }^{3} \mathrm{H}\right]$ tryptamine binding sites, we subjected whole rat brain synaptic membranes to treatment with various protein-modifying reagents and examined the subsequent $\left[{ }^{3} \mathrm{H}\right]$ tryptamine binding properties of the membranes. Pretreatment of the membrane preparations with NEM. NBS. PCMB. PAPMA and MA, but not with iodoacetamide. DTT, glutathione and cysteine, reduced the $\left[{ }^{3} \mathrm{H}\right]$ tryptamine binding. In addition, to at least approx. $10^{-4} \mathrm{M}$. the inactivation properties of NEM, PCMB, PAPMA and MA, except for NBS, were temperature-dependent. Furthermore, it was revealed that the Scatchard plot of $\left[{ }^{3} \mathrm{H}\right]$ tryptamine binding in membranes pretreated with these thiol reagents conformed to a curved line, as well as in the case of the control membranes. Nonlinear regression analysis of these data showed that NEM decreased the $B_{\max }$ values of both the high and low affinity binding sites with no significant alteration in the $K_{D}$ values, whereas PCMB. PAPMA and $M A$ increased only the $K_{\mathrm{I}}$ value of the high affinity sites, accompanying the decrease of the $B_{\max }$ values of both sites. These results indicate that the temperature-induced high-affinity $\left[{ }^{3} \mathrm{H}\right]$ tryptamine binding molecule $(\mathrm{s})$ is a thiol protein.
\end{abstract}

Tryptamine is a pharmacologically active trace amine which influences both human and animal behavior and is implicated in some neurological and psychiatric disorders (1). In addition, iontophoretically applied tryptamine inhibits cortical cell firing independently of 5-HT (2). All these phenomena indicate that tryptamine may be a neurotransmitter or neuromodulator candidate in the central nervous system. On the other hand, recent studies employing radioreceptor-binding assays have found that the $\left[{ }^{3} \mathrm{H}\right]$ tryptamine binding sites. with a $K_{D}$ of approx. $3 \mathrm{nM}$, have the characteristics of specific tryptamine receptors in the brain $(3,4)$

In previous studies $(5,6)$, we reported the

\footnotetext{
- To whom all correspondence should be addressed. Abbreviations used are: NEM. N-ethylmaleimide: NBS. N-bromosuccinimide; PCMB, p-chioromercuribenzoic acid: PAPMA, p-aminophenylmer curic acetate: MA, mercuric acetate: DTT, dithiothreitol; 5-HT. 5-hydroxytryptamine.
}

preincubation conditions that enhance specific $\left[{ }^{3} \mathrm{H}\right]$ tryptamine binding in rat brain synaptic membranes. This phenomenon is fairly dependent on the physiological temperature (i.e., $37^{\circ} \mathrm{C}$ ); and moreover, the glutaraldehyde pretreatment, a known fixative which acts by cross-linking the amine groups of amino acids and blocks the movement of receptor proteins within the lipid bilayer, preferentially inhibits this temperature-induced high-affinity $\left[{ }^{3} \mathrm{H}\right]$ tryptamine binding $\left(K_{D}=0.45 n M\right)$. These observations infer that the preincubationinduced increase in $\left[{ }^{3} \mathrm{H}\right]$ tryptamine binding. in reference to the high affinity proportion of sites, may occur as a result of temperaturedependent interconvertible conformational changes.

There has indeed been an increasing interest in the effects of chemical modifications on neurotransmitter and drug receptor proteins, and many investigations (713) indicate that thiol groups are critical for the ligand binding function of its receptors. 
These considerations prompted us to investigate the biochemical nature of the above mentioned high-affinity $\left[{ }^{3} H\right]$ tryptamine binding sites. Through the present studies, it will be shown that the specific $\left[{ }^{3} \mathrm{H}\right]$ tryptamine binding molecule(s) is a thiol protein and that the existence of the thiol group is essential for the binding of ligands by the temperatureinduced high-affinity sites.

\section{Materials and Methods}

Chemicals: $\quad\left[{ }^{3} \mathrm{H}\right]$ Tryptamine (27.7-39.6 $\mathrm{Ci} / \mathrm{mmol}$ ) was obtained from New England Nuclear. Inc. Other compounds were from Sigma Chemical Co.

Preparation of synaptic membranes: Whole rat brains (male Wistar, 150-200 g), except for the cerebellum and olfactory lobes, were homogenized in $10 \mathrm{vol}$. of $0.32 \mathrm{M}$ sucrose; and synaptic membranes were prepared from this homogenate by a method reported previously (14) with minor modifications. Briefly. the synaptosomal fraction $(0.8-1.2 \mathrm{M}$ sucrose layer) was isolated from the crude mitochondrial fraction $\left(P_{2}\right)$ by discontinuous sucrose $(0.32,0.8$ and $1.2 \mathrm{M})$ density gradient centrifugation $(53,500 \times \mathrm{g}$ for $2 \mathrm{hr}$ ) and then was lysed with water for $30 \mathrm{~min}$ at $0^{\circ} \mathrm{C}$ (10 $\mathrm{ml} / \mathrm{g}$ of original tissue). The sample was loaded onto a two-step sucrose gradient $(0.8$ and $1.2 \mathrm{M}$ ). After similar centrifugation, the 0.8 and $1.2 \mathrm{M}$ layers were collected and were designated as the synaptic membrane fraction. Finally, this fraction was diluted with an equal volume of water and centrifuged at $1 \times$ $10^{5} \times \mathrm{g}$ for $30 \mathrm{~min}$. The resultant pellets were suspended in $0.05 \mathrm{M}$ Tris- $\mathrm{HCl}$ buffer. $[\mathrm{pH} 7.4$ (i.e.. Tris buffer) $4 \mathrm{mg}$ protein $/ \mathrm{ml}$ ] and quickfrozen under liquid $\mathrm{N}_{2}$ and stored at $-75^{\circ} \mathrm{C}$ until used. generally $1-3$ weeks.

Pretreatment of membranes with various protein-modifying reagents: After rapid thawing of the frozen membranes, samples were pretreated with various reagents in Tris buffer (2 $\mathrm{mg}$ protein $/ \mathrm{ml}$ ) for $55 \mathrm{~min}$ at $37^{\circ} \mathrm{C}$. Preincubation was terminated by addition of the same buffer, ice-cold. and a brief immersion in an ice bath. followed rapidly by centrifugation $(27,000 \times \mathrm{g}$ for $25 \mathrm{~min})$. In the case of thiol reagents, reactions were stopped by the addition of $10 \mathrm{mM}$ cysteine that rapidly inactivates excess reagents and also washed once by centrifugation $(27,000 \times \mathrm{g}$ for $25 \mathrm{~min}$ ) with Tris buffer. All the resultant pellets were resuspended in $0.05 \mathrm{M}$ Tris- $\mathrm{HCl}$ buffer $(\mathrm{pH}$ 7.4) containing $0.1 \%$ ascorbic acid and $10 \mu \mathrm{M}$ pargyline (i.e.. standard assay medium) and were supplied for the binding assay of $\left[{ }^{3} \mathrm{H}\right]$ tryptamine. All reagents were dissolved in Tris buffer immediately before use except for PCMB, PAPMA and MA, which were dissolved in $2.5 \%$ dimethylsulfoxide (DMSO). (DMSO and cysteine has no effect on the binding at each concentration.)

$\left[{ }^{3} \mathrm{H}\right]$ Tryptamine binding assay: Radioreceptor-binding assay was done essentially as described by Cascio and Kellar (3). A $0.5 \mathrm{ml}$ aliquot of membrane suspension (approx. $500 \mu \mathrm{g}$ protein) was added to tubes containing $\left[{ }^{3} \mathrm{H}\right]$ tryptamine and standard assay medium. Half of the tubes also contained 10 $\mu \mathrm{M}$ of unlabelled tryptamine to measure nonspecific binding. The tubes $(1.0 \mathrm{ml})$ were incubated at $0^{\circ} \mathrm{C}$ for $60 \mathrm{~min}$ and then rapidly filtered under a vacuum through Whatman GF/B filters with five rinses of $5 \mathrm{ml}$ ice-cold Tris buffer. The filters were counted by a liquid scintillation counter in $10 \mathrm{ml}$ of toluene/ Triton $X-100$ (3:1) emulsion phosphor. The specific binding of $\left[{ }^{3} \mathrm{H}\right]$ tryptamine was defined as the total minus nonspecific binding. Every determination of binding was performed in triplicate, and the bound radioactivities were identified as $\left[{ }^{3} \mathrm{H}\right]$ tryptamine itself by a quantitative TLC method reported previously (5). Membranous protein was determined by the SDS-Lowry method of Lees and Paxman (15). The Scatchard plot data were computerassessed by nonliner regression analysis as reported previously (16). F-test analysis ( $P<$ $0.01)$ was used to determine whether a onesite or two-site model was more appropriate.

\section{Results}

The results of the effects of various reagents on $\left[{ }^{3} \mathrm{H}\right]$ tryptamine binding are exhibited in Table 1 . The $\left[{ }^{3} \mathrm{H}\right]$ ligand was used in a concentration of $3 \mathrm{nM}$ for the binding assay. NEM, NBS, PCMB, PAPMA and MA all diminished $\left[{ }^{3} \mathrm{H}\right]$ tryptamine binding dose-dependently. On the contrary, iodoacetamide. and the disulfide bridge-reducing reagents, DTT, glutathione and cysteine, had no effect. Moreover, to investigate the characteristics of 
Table 1. Effects of various reagents on $\left[{ }^{3} \mathrm{H}\right]$ tryptamine binding

\begin{tabular}{|c|c|}
\hline Reagent (M) & {$\left[{ }^{3} \mathrm{H}\right]$ Tryptamine bound (\%) } \\
\hline \multicolumn{2}{|c|}{ Hydrophilic reagents } \\
\hline \multicolumn{2}{|c|}{ NEM } \\
\hline $1 \times 10^{-5}$ & $99.0 \pm 2.8$ \\
\hline $1 \times 10^{-4}$ & $50.4 \pm 2.1$ \\
\hline $5 \times 10^{-4}$ & $14.7 \pm 3.0$ \\
\hline \multicolumn{2}{|l|}{ NBS } \\
\hline $1 \times 10^{-5}$ & $101.6 \pm 10.4$ \\
\hline $1 \times 10^{-4}$ & $54.0 \pm 5.2$ \\
\hline $5 \times 10^{-4}$ & $14.6 \pm 2.8$ \\
\hline \multicolumn{2}{|c|}{ lodoacetamide } \\
\hline $1 \times 10^{-5}$ & $104.9 \pm 5.9$ \\
\hline $1 \times 10^{-4}$ & $99.1 \pm 0.6$ \\
\hline $5 \times 10^{-4}$ & $99.9 \pm 2.3$ \\
\hline \multicolumn{2}{|c|}{ Lipophilic reagents } \\
\hline \multicolumn{2}{|c|}{ PCMB } \\
\hline $1 \times 10^{-5}$ & $100.9 \pm 2.6$ \\
\hline $1 \times 10^{-4}$ & $56.7 \pm 4.0$ \\
\hline $5 \times 10^{-4}$ & $0.4 \pm 0.2$ \\
\hline \multicolumn{2}{|l|}{ PAPMA } \\
\hline $1 \times 10^{-5}$ & $96.0 \pm 2.3$ \\
\hline $1 \times 10^{-4}$ & $46.8 \pm 0.3$ \\
\hline $5 \times 10^{-4}$ & $3.8 \pm 0.6$ \\
\hline \multicolumn{2}{|l|}{ MA } \\
\hline $1 \times 10^{-6}$ & $96.6 \pm 5.2$ \\
\hline $5 \times 10^{-5}$ & $60.9 \pm 8.6$ \\
\hline $1 \times 10^{-4}$ & $4.1 \pm 1.1$ \\
\hline \multicolumn{2}{|l|}{ Others } \\
\hline \multicolumn{2}{|l|}{ DTT } \\
\hline $1 \times 10^{-4}$ & $100.5 \pm 6.5$ \\
\hline $5 \times 10^{-4}$ & $99.1 \pm 2.4$ \\
\hline \multicolumn{2}{|l|}{ Glutathione } \\
\hline $1 \times 10^{-4}$ & $99.7 \pm 9.5$ \\
\hline $1 \times 10^{-3}$ & $100.9 \pm 5.2$ \\
\hline \multicolumn{2}{|l|}{ Cysteine } \\
\hline $1 \times 10^{-4}$ & $104.7 \pm 7.5$ \\
\hline $1 \times 10^{-3}$ & $101.7 \pm 2.3$ \\
\hline
\end{tabular}

Rat brain synaptic membranes were suspended at a concentration of $2 \mathrm{mg} / \mathrm{ml}$ in $0.05 \mathrm{M}$ Tris- $\mathrm{HCl}$ buffer $\left(\mathrm{pH} \mathrm{7.4)}\right.$ containing various reagents as indicated. The mixtures were preincubated for 55 min at $37^{\circ} \mathrm{C}$. and the subsequent specific binding capacities of the membranes were measured with $3 \mathrm{nM}\left[{ }^{3} \mathrm{H}\right]$ tryptamine as described in the text. The data are expressed as a percent of the control value (meantS.E.M. of 4 experiments). Control: $14031 \pm 800 \mathrm{dpm} / \mathrm{mg}$ protein.

the inhibitory potencies of these thiol reagents, we examined the effect of temperature on the rate of inactivation of $\left[{ }^{3} \mathrm{H}\right]$ tryptamine binding. As presented in Table 2, at an appropriate concentration $\left(1 \times 10^{-4}\right.$ or $7 \times$ $\left.10^{-5} \mathrm{M}\right)$. the inactivation properties of NEM. PCMB, PAPMA and MA, but not of NBS, are temperature-dependent, in that if the preincubation of membranes $w$ ith these reagents is performed at $0^{\circ} \mathrm{C}$, there is no subsequent inactivation of $\left[{ }^{3} \mathrm{H}\right]$ ligand binding.

To clarify the mode of action of NEM. PCMB, PAPMA or MA on the high-affinity tryptamine binding sites, we performed a Scatchard analysis of $\left[{ }^{3} \mathrm{H}\right]$ tryptamine binding to the membrane preparations pretreated with these reagents. As can be seen in Fig. 1, the Scatchard plot of $\left[{ }^{3} \mathrm{H}\right]$ tryptamine binding in 
Table 2. Effect of temperature on the inactivation of $\left[{ }^{3} \mathrm{H}\right]$ tryptamine binding to synaptic membranes by several thiol reagents

\begin{tabular}{|c|c|c|c|}
\hline \multirow{2}{*}{ Reagent $(M)$} & \multicolumn{2}{|c|}{$\left[{ }^{3} \mathrm{H}\right]$ Tryptamine bound (\%) } & \\
\hline & $37^{\circ} \mathrm{C}^{\mathrm{a}}$ & $0^{\circ} \mathrm{C}$ & \\
\hline \multicolumn{4}{|l|}{ NEM } \\
\hline $1 \times 10^{-5}$ & $99.0 \pm 2.8$ & $100.0 \pm$ & 0.8 \\
\hline $1 \times 10^{-4}$ & $50.4 \pm 2.1$ & $102.1 \pm$ & 5.0 \\
\hline $5 \times 10^{-4}$ & $14.7 \pm 3.0$ & $67.3 \pm$ & 2.0 \\
\hline \multicolumn{4}{|l|}{ NBS } \\
\hline $1 \times 10^{-5}$ & $101.6 \pm 10.4$ & $103.6 \pm$ & 3.5 \\
\hline $1 \times 10^{-4}$ & $54.0 \pm 5.2$ & $73.8 \pm$ & 4.9 \\
\hline $5 \times 10^{-4}$ & $14.6 \pm 2.8$ & $23.7 \pm$ & 1.4 \\
\hline \multicolumn{4}{|l|}{ PCMB } \\
\hline $1 \times 10^{-5}$ & $100.9 \pm 2.6$ & $100.7 \pm$ & 3.3 \\
\hline $1 \times 10^{-4}$ & $56.7 \pm 4.0$ & $100.4 \pm$ & 2.2 \\
\hline $5 \times 10^{-4}$ & $0.4 \pm 0.2$ & $68.6 \pm 1$ & 10.2 \\
\hline \multicolumn{4}{|l|}{ PAPMA } \\
\hline $1 \times 10^{-5}$ & $96.0 \pm 2.3$ & $100.0 \pm$ & 1.8 \\
\hline $1 \times 10^{-4}$ & $46.8 \pm 0.3$ & $99.2 \pm$ & 4.8 \\
\hline $5 \times 10^{-4}$ & $3.8 \pm 0.6$ & $49.1 \pm$ & 7.6 \\
\hline \multicolumn{4}{|l|}{ MA } \\
\hline $1 \times 10^{-5}$ & $96.6 \pm 5.2$ & $100.0 \pm$ & 1.7 \\
\hline $7 \times 10^{-5}$ & $27.3 \pm 4.3$ & $100.0 \pm$ & 4.4 \\
\hline $1 \times 10^{-4}$ & $4.1 \pm 1.1$ & $54.0 \pm$ & 1.2 \\
\hline
\end{tabular}

Rat brain synaptic membranes were preincubated with several thiol reagents for $55 \mathrm{~min}$ at $37^{\circ} \mathrm{C}$ or $0^{\circ} \mathrm{C}$, and then their specific binding was measured with $3 \mathrm{nM}\left[{ }^{3} \mathrm{H}\right]$ tryptamine as described in the text. The results are expressed as a percent of the control values (mean \pm S.E.M. of 4 experiments). aData from Table 1, except for the value of $7 \times 10^{-5} \mathrm{M}$ MA. Control: at $37^{\circ} \mathrm{C}, 14031 \pm 800$ and at $0^{\circ} \mathrm{C}, 5770 \pm 250$ $\mathrm{dpm} / \mathrm{mg}$ protein.

Table 3. Scatchard analysis of $\left[{ }^{3} \mathrm{H}\right]$ tryptamine binding to synaptic membranes pretreated with several thiol reagents

\begin{tabular}{|c|c|c|c|c|}
\hline \multirow{2}{*}{ Reagent (M) } & \multicolumn{2}{|c|}{ High-affinity sites } & \multicolumn{2}{|c|}{ Low-affinity sites } \\
\hline & $K_{D^{a}}$ & $B_{\max }{ }^{b}$ & $K_{D^{a}}$ & $\mathrm{~B}_{\max }{ }^{\mathrm{b}}$ \\
\hline Control & $\begin{array}{l}0.45 \\
\pm 0.01\end{array}$ & $\begin{array}{l}106.8(100) \\
\pm 12.6\end{array}$ & $\begin{array}{l}31.9 \\
\pm 0.5\end{array}$ & $\begin{array}{l}656.9(100) \\
\pm 42.3\end{array}$ \\
\hline $\begin{array}{l}\text { NEM } \\
\qquad 1 \times 10^{-4}\end{array}$ & $\begin{array}{l}0.44 \\
\pm 0.02\end{array}$ & $\begin{array}{l}60.6(57) \\
\pm 4.5\end{array}$ & $\begin{array}{l}33.2 \\
\pm 2.6\end{array}$ & $\begin{array}{l}399.4(61) \\
\pm 33.5\end{array}$ \\
\hline $\begin{array}{l}\text { PCMB } \\
\quad 1 \times 10^{-4}\end{array}$ & $\begin{array}{l}0.72 \\
\pm 0.03\end{array}$ & $\begin{array}{l}75.0(70) \\
\pm 2.2\end{array}$ & $\begin{array}{l}30.6 \\
\pm 1.3\end{array}$ & $\begin{array}{l}474.3(72) \\
\pm 37.4\end{array}$ \\
\hline $\begin{array}{l}\text { PAPMA } \\
1 \times 10^{-4}\end{array}$ & $\begin{array}{l}1.07 \\
\pm 0.07\end{array}$ & $\begin{array}{l}59.6(56) \\
\pm 11.7\end{array}$ & $\begin{array}{l}34.0 \\
\pm 1.2\end{array}$ & $\begin{array}{l}394.1(60) \\
\pm 62.4\end{array}$ \\
\hline $\begin{array}{l}\text { MA } \\
\qquad 7 \times 10^{-5}\end{array}$ & $\begin{array}{l}1.38 \\
\pm 0.11\end{array}$ & $\begin{array}{l}38.1(36) \\
\pm 8.7\end{array}$ & $\begin{array}{l}30.4 \\
\pm 1.3\end{array}$ & $\begin{array}{l}264.1(40) \\
\pm 28.2\end{array}$ \\
\hline
\end{tabular}

Rat brain synaptic membranes were pretreated with several thiol reagents. After pretreatment, the control membranes and the treated membranes were incubated with various concentrations of $\left[{ }^{3} \mathrm{H}\right]$ tryptamine and Scatchard plots were performed as shown in Fig. 1. The plot data were computer-assessed by nonlinear regression analysis as described in the text. Values are expressed as the meantS.E.M. of 4 experiments. ${ }^{a} K_{D}: n M,{ }^{b} B_{\max }$ fmoles/mg protein. 


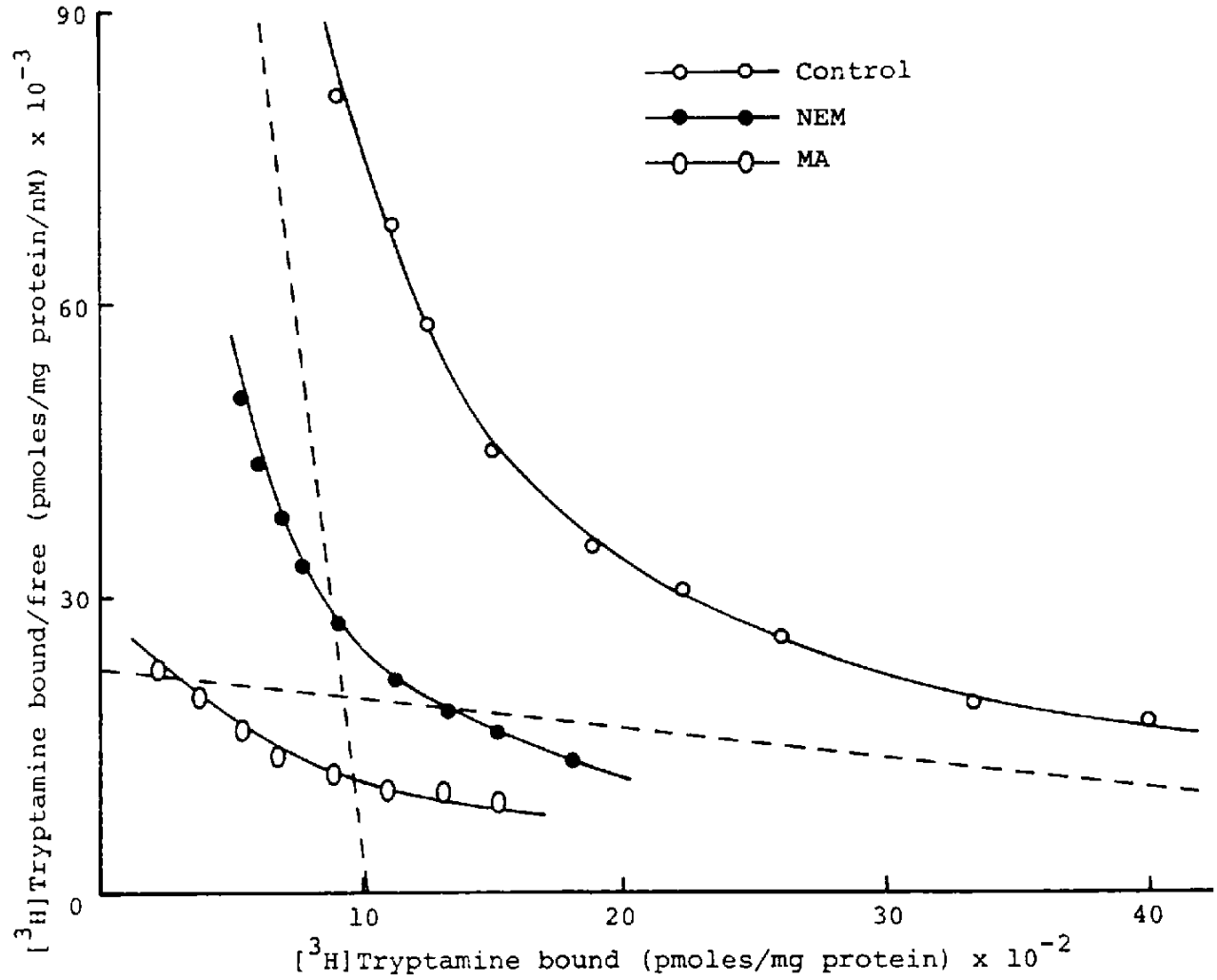

Fig. 1. Scatchard plots of [ $\left.{ }^{3} \mathrm{H}\right]$ tryptamine binding: Effect of NEM and MA pretreatment. Membrane preparations were pretreated with $1 \times 10^{-4} \mathrm{M} \mathrm{NEM}$ and $7 \times 10^{-5} \mathrm{M} \mathrm{MA}$. After pretreatment, the subsequent $\left[{ }^{3} \mathrm{H}\right]$ tryptamine $(1-25 \mathrm{nM})$ binding capacities of the control membranes and the treated membranes were estimated as described in the text. The resuits shown are those of a typical experiment, performed 4 times. The computer-generated curves were derived from nonlinear regression analysis, and the two dashed lines were drawn theoretically from the curvilinear plot of the control using a two-site model.

the control membranes conformed to a curved line and non-linear regression analysis demonstrated the presence of high and low affinity sites, as shown with the dashed lines. The thiol reagent-pretreated membranes also yielded curvilinear Scatchard plots. However, two types of inhibitory modes were observed. One is apparently noncompetitive inhibition. and this type occurred with treatment by the hydrophilic reagent NEM. The other is with the lipophilic reagent. MA (and also PCMB or PAPMA, data not shown), which showed a mixed type of inhibition.

The Scatchard plot data were computerassessed by nonlinear regression analysis. and the results obtained are summarized in Table 3. As we have already reported, temperature-sensitive $\left[{ }^{3} \mathrm{H}\right]$ tryptamine binding sites are composed of high and low affinity sites. The respective apparent $K_{D}$ and $B_{\max }$ values of each site were 0.45 and $31.9 \mathrm{nM}$ and 106.8 and $656.9 \mathrm{fmoles} / \mathrm{mg}$ protein. Interesting differences in the effects of thiol reagents on the binding parameters were observed, as can be seen in Table 3. Namely, the hydrophilic reagent NEM decreased the $B_{\max }$ values of both the high and low affinity sites and had no effect on the $K_{\mathrm{p}}$ values. On the other hand, the lipophilic reagents PCMB. PAPMA and MA increased only the $K_{D}$ value of the high affinity sites, although these reagents decreased the $B_{\max }$ values of both sites. In addition, we could not find any statistically significant difference (at $\mathrm{P}<0.05$ ) between the decrement of the $B_{\max }$ values of the high and low affinity sites. 


\section{Discussion}

An interesting question is whether the preincubation (i.e., temperature)-induced highaffinity $\left[{ }^{3} \mathrm{H}\right]$ tryptamine binding sites have the pharmacological characteristics of putative tryptamine receptors similar to those observed by other investigators $(3,4)$. Concerning this matter, in our preliminary study (6) that the apparent $K_{1}$ values of tryptamine, 5 -fluorotryptamine, harmaline, tetrahydro- $\beta$ carboline, kynuramine, 5-methoxytryptamine and $5-\mathrm{HT}$ for this portion of the high-affinity sites indicate that their inhibitory potencies are 2-5 times those reported previously (3. 4). Furthermore, the receptor proteins are more sensitive to thiol reagents, as already described elsewhere. Therefore, assuming a possible involvement of the above-mentioned high-affinity $\left[{ }^{3} \mathrm{H}\right]$ tryptamine binding sites in tryptamine receptor mechanisms as receptor proteins, in the present studies, we treated whole rat brain synaptic membranes with various protein-modifying reagents and examined the biochemical nature of their $\left[{ }^{3} \mathrm{H}\right]$ tryptamine binding sites.

In the present experiments (Table 1), pretreatment of the membrane preparations with NEM, NBS, PCMB. PAPMA and MA, but not with iodoacetamide, caused a diminution of $\left[{ }^{3} \mathrm{H}\right]$ tryptamine binding. Likewise, a similar discrepancy between iodoacetamine and NEM effects was also reported for dopamine (8) or histamine receptors (10), and this may be attributed to a participation of the microenvironment of the thiol in the accessibility or reactivity of the latter to various thiol reagents. Furthermore, to investigate the characteristics of the inhibitory potencies of these thiol reagents, we examined the effect of temperature on the rate of inactivation of $\left[{ }^{3} \mathrm{H}\right]$ tryptamine binding, because the pretreatment condition of these reagents (i.e., 55 -min incubation at $37^{\circ} \mathrm{C}$ ) also corresponds to the preincubation conditions of the membranes that induce the augmentation of specific $\left[{ }^{3} \mathrm{H}\right]$ tryptamine binding. To at least approx. $10^{-4} \mathrm{M}$, the inactivation properties of NEM. PCMB, PAPMA and MA, except for NBS, were temperature-dependent (Table 2). In addition, this inactivation can be prevented by prior addition of an equimolar concentration of DTT to the membranes (data not shown). suggesting that these reagents are exerting their effects via modification of thiol groups associated with the $\left[{ }^{3} \mathrm{H}\right]$ tryptamine binding sites. Thus, in order to learn more about the specificity of thiol reagents, we applied appropriate concentrations of NEM, PCMB. PAPMA and MA and carried out the following experiments with Scatchard analysis.

Since the pretreatment with thiol reagents and the preincubation of membranes, i.e.. induction of the temperature-sensitive highaffinity $\left[{ }^{3} \mathrm{H}\right]$ tryptamine binding sites, should be done simultaneously, we could not investigate directly whether or not the prior treatment with agonist, e.g., tryptamine, protects the high-affinity binding sites from thiol reagents. Of the components of the hormonesensitive adenylate cyclase, both the catalytic unit and the guanine nucleotide-binding regulatory proteins are also sensitive to reagents which alkylate thiol residues, as well as the cell surface receptors (17). However, as yet we have only limited knowledge of the nature of the molecular events involved in the coupling of tryptamine receptor activation to the final biological responses.

In conclusion, the data demonstrated for the first time that the specific $\left[{ }^{3} \mathrm{H}\right]$ tryptamine binding molecule (s) is a thiol protein, and the differential mode of action of the hydrophilic and lipophilic reagents suggests that the existence of the thiol group in a hydrophobic environment such as an intramembrane site is essential for the binding of ligands by the high-affinity sites (Fig. 1 and Table 3). In other words, the high-affinity binding sites are more lipophilic in nature than the low affinity sites. This concept is further supported by our other findings ( $R$. Ishitani et al., unpublished observation). Namely, in the phospholipase $A_{2}$-treated membranes, only the $K_{\mathrm{D}}$ value of the high-affinity binding sites was increased, together with the decrease of $B_{\max }$ values of both binding sites. Thus, we speculate that certain acidic lipids may play an important role in the molecular constitution of the high-affinity binding sites, as well as in the case of $5-\mathrm{HT}_{1}$ receptors (18). Finally, all data presented here strongly suggest the neurophysiological relevance of these high-affinity binding molecules as 
receptor proteins.

\section{References}

1 Yu, P.H., Davis, B.A., Bowen, R.D., Wormith, S., Addington, D. and Boulton, A.A.: The catabolism of trace amines in some psychiatric disorders. In Neurobiology of the Trace Amines: Analytical. Physiological, Pharmacological, Behavioral and Clinical Aspects, Edited by Boulton, A.A., Baker, G.B., Dewhurst. W.G. and Sandler, M., p. 475486. Hamana Press, Clifton (1984)

2 Jones, R.S.G.: Tryptamine: A neuromodulator or neurotransmitter in mammalian brain? Prog. Neurobiol. 19, 117-139 (1982)

3 Cascio, C.S. and Kel!ar, K.J.: Characterization of $\left[{ }^{3} \mathrm{H}\right]$ tryptamine binding sites in brain. Eur. J. Pharmacol. 95, 31-39 (1983)

4 Brüning, G. and Rommelspacher, H.: High affinity $\left[{ }^{3} \mathrm{H}\right]$ tryptamine binding sites in various organs of the rat. Life Sci. 34, 1441-1446 (1984)

5 Karasawa, A., Serikyaku, S. and Ishitani, R.: Temperature-sensitive high affinity $\left[{ }^{3} \mathrm{H}\right]$ tryptamine binding sites in rat brain. Life Sci. 38, 1331-1337 (1986)

6 Serikyaku, S. and Ishitani, R.: Glutaraldehyde pretreatment blocks temperature-induced highaffirity $\left[{ }^{3} \mathrm{H}\right]$ tryptamine binding. Life Sci. 42, 207-214 (1988)

7 Strauss, W.L. and Venter, J.C.: A sulfhydryl group of the canine cardiac beta-adrenergic receptor observed in the absence of hormone. Life Sci. 36, 1699-1706 (1985)

8 Suen, E.T., Stefanini, E. and Clement-Cormier, Y.C.: Evidence for essential thiol groups and disulfide bonds in agonist and antagonist binding to the dopamine receptor. Biochem. Biophys. Res. Commun. 96, 953-960 (1980)

9 Biassoni, R. and Vaccari, A.: Selective effects of thiol reagents on the binding sites for imipra- mine and neurotransmitter amines in the rat brain. Br. J. Pharmacol. 85, 447-456 (1985)

10 Yeramian, E., Garbarg, M. and Schwartz, J.-C.: $\mathrm{N}$-Ethylmaleimide-induced changes in agonist affinity for histamine $\mathrm{H}_{1}$-receptors in the guinea pig brain. Mol. Pharmaco!. 28, 155-162 (1985)

11 Ukena, D., Poeschla, E., Hüttemann, E. and Schwabe, U.: Effects of $\mathrm{N}$-ethylmaleimide on adenosine receptors of rat fat cells and human platelets. Naunyn Schmiedebergs Arch. Pharmacol. 327, 247-253 (1984)

12 Pasternak, G.W., Wilson, H.A. and Snyder, S.H.: Differential effects of protein-modifying reagents on receptor binding of opiate agonists and antagonists. Mol. Pharmacol. 11, 340-351 (1975)

13 Martini, C. and Lucacchini, A.: Inactivation of benzodiazepine binding sites by $\mathrm{N}$-ethylmaleimide. J. Neurochem. 38, 1768-1770 (1982)

14 Ishitani, R., Satoh, T., Suga, T. and Kitagawa, H.: 5 tudies on the ultrastructural distribution of ${ }^{3} \mathrm{H}$ dimetacrine in rat cerebral cortex. Japan. J. Pharmacol. 22, 313-323 (1972)

15 Lees, M.B. and Paxman, S.: Modification of the Lowry procedure for the analysis of proteolipid protein. Anal. Biochem. 47, 184-192 (1972)

16 Yoshikawa, S. and Ishitani, R.: Selective labelling of high affinity 5-hydroxytryptamine receptors in whole rat brain. Neuropharmacology 23, 1227-1230 (1984)

17 Ross, E.M., Howlett, A.C., Ferguson, K.M. and Gilman, A.G.: Reconstitution of hormonesensitive adenylate cyclase activity with resolved components of the enzyme. J. Biol. Chem. 253, 6401-6412 (1978)

18 Yoshikawa, S. and Ishitani, R.: Implication of acidic lipids in 5-hydroxytryptamine receptor mechanisms. Life Sci. 36, 485-492 (1985) 